UDC 634.22:581.47(497.11)"2013"

Original research paper

doi: 10.5937/AASer1948181I

Acta Agriculturae Serbica, Vol. XXIV, 48(2019); 181-190

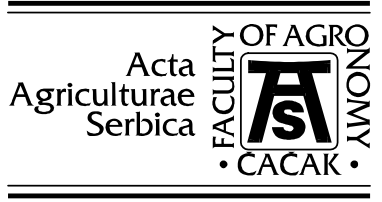

\title{
Influence of the rootstock on the physical-mechanical properties of the plum fruit (Prunus domestica $\mathbf{L}$.)
}

\author{
Radmila Ilić, Ivan Glišić, Tomo Milošević, Gorica Paunović \\ Department of Fruit Growing and Viticulture, Faculty of Agronomy, University of \\ Kragujevac, 32000, Čačak, Serbia \\ Corresponding author: radmila.nikolic@kg.ac.rs
}

\begin{abstract}
The research was conducted in the experimental-production plum orchard during 2013. Some of the most important physical and mechanical properties of the fruit were investigated in three plum cultivars ('Čačanska Rana', 'Čačanska Lepotica' i 'Čačanska Najbolja') grafted on four rootstocks: one generative Myrobalan (Prunus cerasifera Ehrh.) and three vegetative ones (Pixy, St. Julien A and Ferley). St. Julien A induced the highest all three fruit dimensions in 'Čačanska Najbolja', and length and thickness in 'Čačanska Lepotica'. Myrobalan and Fereley had the same effect in the 'Čačanska Rana'. St. Julien A influenced the biggest fruit firmness in 'Čačanska Najbolja' and the smallest in 'Čačanska Lepotica'.
\end{abstract}

Keywords: plum, cultivar, fruit dimensions, fruit firmness.

\section{Introduction}

Domestic or European plum (Prunus domestica L.) is the most represented and traditionally the most important fruit species in Serbia. According to data from relevant literature, Serbia was ranked second in Europe in 2017 in terms of production of this fruit species, and fourth in the world, just behind China, Romania and the USA with production of $330582 \mathrm{t}$ (FAOSTAT, 2019). This means that plum is of great economic and social importance to Serbia. However, despite being produced in such large quantities, the production itself is still at the level of extensive and semi-intensive, due to the low level of cultivation technology and Plum Pox Virus (PPV), and due to numerous other factors, primarily the instability of the domestic and foreign markets. 
Considering its importance, both in our country and in the world, intensive work is being done on advancement of plum cultivation. The main goals of breeding are early and regular fertility, self-fertilization, extension of the harvest season, attractive, large and high quality fruits suitable for both table usage, drying and processing as well as resistance to the most important pathogens such as PPV, Monilinia laxa (Aderh. \& Ruhl.) etc. (Mišić, 2002).

One of the most important areas of plum cultivation in this country is western Serbia, and within it the most significant production center is Čačak (Milošević and Milošević,

Recently, there has been a large selection of plum cultivars highly tolerant to PPV, very productive, early bearing, with attractive, large and tasty fruits. The most popular plum cultivars in Serbia are 'Stanley', 'Čačanska Lepotica', Čačanska Rodna, 'Čačanska Najbolja' and 'Čačanska Rana' (Milošević and Milošević, 2011). However, it is important to emphasize that it is not enough to choose a good cultivar, but also the appropriate rootstocks for raising orchards. One of the basic pre-requestes for intensification of plum production in the world is considered to be selection of the vegetative rootstocks of different vigourness (Paunović, 2008). Today, there is still modest knowledge about the positive and negative effects of particular rootstocks on particular cultivars. It has been long known that the soil and weather conditions can significantly affect the vegetative growth, yield and fruit quality (Sosna, 2002). As Paunović et al. (2011) stated, the most commonly used rootstock in Serbia is the seedling of Myrobalan. Unfortunately, it is not the best plum rootstock, especially very vigour types and varieties. The grafting of the plum scion to the clonal rootstocks with lower vigour reduces the tree vigour, resulting in more trees per unit area, which aims of achieving higher yields and better fruit quality.

Knowledge about clonal rootstocks, their behavior in orchards, impacts on tree growth, productivity and fruit quality is very limited for Serbian plum growers. From these reasons, some of clonal rootstocks have been investigated in this research. So, in this study, we evaluated the most important physical and mechanical traits of the fruit of three plum cultivars grafted onto four rootstocks: one generative Myrobalan and three vegetative Pixy, St. Julien A and Ferley grown in high density planting system under Serbian conditions.

\section{Materials and methods}

The research was carried out in the experimental-productive plum orchard during 2013.

Orchard is located in Gornja Gorevnica vilage, $9 \mathrm{~km}$ north-west of Čačak (205' 48'”N, 20¹9'31'”E, $396 \mathrm{~m}$ above sea level).

The orchard was established in autumn of 2009. The planting distance is $3.8 \mathrm{~m}$ between rows and $1.8 \mathrm{~m}$ in row, which corresponds to a density of 1.462 trees/ha. Each combination rootstock-cultivar was represented with 4 replications and 4 trees per replication $(n=16)$. 
Three plum varieties were used as test material: 'Čačanska Lepotica', 'Čačanska Najbolja' and 'Čačanska Rana' grafted on four rootstocks: Myrobalan (invigorating), Pixy (dwarf), St. Julien A and Ferley (semi-dwarf). All trees of 'Čačanska Rana' have died on St. Julien A for unknown reasons, and therefore description of the behavior of this cultivar- rootstock combination was not possible.

In this experiment, we investigated main physical-mechanical characteristics of fruits, such as fruit linear dimensions, fruit firmness, arithmetic and geometric mean diameter and sphericity index. Twenty fruits in four replicates $(n=80)$ were randomly harvested from each rootstock-cultivar combination at full maturity stage and used for analysis.

Fruit length (L), width (W) and thickness (T) were determined using a Starret 727 Series digital caliper (Athol, MA, USA). Values are expressed in mm. The fruit firmness was determined using a Bertuzzi FT-327 penetrometer (Facchini, Alfonsine, Italy), and values were expressed in $\mathrm{kg} / \mathrm{cm}^{2}$.

The arithmetic and geometric mean diameter and sphericity were obtained using mathematical forms proposed by Mohsenin, 1986.

Polar (L), suture (W) and equatorial (T) diameters were measured and then transformed to the parameter denominated "size" or mean arithmetic (Eq. 1) and mean geometric diameter (Eq. 2) defined as:

$$
\begin{aligned}
& D_{a}=\frac{L+W+T}{3} \\
& D_{g}=\sqrt[3]{L W T}
\end{aligned}
$$

where: $\mathrm{D}_{\mathrm{a}}$ - arithmetic mean diameter in $\mathrm{mm}(1)$ and $\mathrm{D}_{\mathrm{g}}-$ geometric mean diameter in $\mathrm{mm}(2)$.

Sphericity was defined by using the following equation:

$$
\varphi=\frac{D_{g}}{L}
$$

where: $\varphi$ - sphericity

Data were statistically processed by analysis of variance (ANOVA) of a one-factor view using Microsoft Excel software package (Microsoft Corporation, Roselle, IL, USA). When the $F$ test was significant, the means were tested with the least significant difference test (LSD test) for a significance threshold of $P \leq 0.05$.

\section{Results and discussion}

The results relating to the linear dimensions of the fruit are presented in Table 1. The data show that the influence of rootstocks on these parameters is not consistent across varieties. Myrobalan and Ferley conditioned similar and the highest values of fruit length and thickness, with only Myrobalan having the greatest width of fruit in 'Čačanska Rana'. St. Julien A influenced the largest dimensions of the fruit in 'Čačanska Najbolja'. Pixy caused the smallest dimensions of fruit in 'Čačanska Rana' 
and 'Čačanska Najbolja'. Pixy also caused the smallest thickness and Myrobalan the smallest fruit length in the 'Čačanska Lepotica'. In 'Čačanska Lepotica', the rootstocks did not significantly influenced fruit width, while the maximum length and thickness of the fruit were determined on St. Julien A.

Table 1. Linear dimensions of fruit and fruit firmness of three plum varieties grafted on different rootstocks

\begin{tabular}{llllll}
\hline Cultivar & Rootstock & $\begin{array}{l}\text { Fruit length } \\
(\mathrm{mm})\end{array}$ & $\begin{array}{l}\text { Fruit width } \\
(\mathrm{mm})\end{array}$ & $\begin{array}{l}\text { Fruit thickness } \\
(\mathrm{mm})\end{array}$ & $\begin{array}{l}\text { Fruit firmness } \\
\left(\mathrm{kg} / \mathrm{cm}^{2}\right)\end{array}$ \\
\hline ‘Čačanska Rana' & Pixy & $48.20 \pm 0.36 \mathrm{~b}$ & $38.12 \pm 0.18 \mathrm{c}$ & $37.30 \pm 0.17 \mathrm{~b}$ & $3.75 \pm 0.12 \mathrm{a}$ \\
& St. Julien A & - & - & - & - \\
& Fereley & $50.70 \pm 0.30 \mathrm{a}$ & $40.04 \pm 0.19 \mathrm{~b}$ & $39.28 \pm 0.27 \mathrm{a}$ & $3.71 \pm 0.11 \mathrm{a}$ \\
& Myrobalan & $51.90 \pm 0.41 \mathrm{a}$ & $41.18 \pm 0.34 \mathrm{a}$ & $39.23 \pm 0.37 \mathrm{a}$ & $3.83 \pm 0.11 \mathrm{a}$ \\
& & & & \\
& & & & \\
& Pixy & $40.68 \pm 0.28 \mathrm{bc}$ & $35.11 \pm 0.19 \mathrm{a}$ & $33.42 \pm 0.24 \mathrm{c}$ & $3.94 \pm 0.11 \mathrm{ab}$ \\
& St. Julien A & $41.68 \pm 0.30 \mathrm{a}$ & $36.21 \pm 0.20 \mathrm{a}$ & $35.14 \pm 0.27 \mathrm{a}$ & $3.67 \pm 0.22 \mathrm{~b}$ \\
& Fereley & $40.84 \pm 0.31 \mathrm{~b}$ & $35.12 \pm 0.26 \mathrm{a}$ & $34.79 \pm 0.26 \mathrm{ab}$ & $4.19 \pm 0.11 \mathrm{a}$ \\
& Myrobalan & $40.47 \pm 0.46 \mathrm{c}$ & $34.77 \pm 0.55 \mathrm{a}$ & $34.34 \pm 0.32 \mathrm{~b}$ & $4.28 \pm 0.12 \mathrm{a}$ \\
& & & & \\
‘Čačanska Najbolja' & Pixy & $39.59 \pm 0.35 \mathrm{c}$ & $33.18 \pm 0.25 \mathrm{c}$ & $31.44 \pm 0.23 \mathrm{c}$ & $2.63 \pm 0.10 \mathrm{c}$ \\
& St. Julien A & $42.84 \pm 0.46 \mathrm{a}$ & $35.88 \pm 0.29 \mathrm{a}$ & $35.38 \pm 0.21 \mathrm{a}$ & $4.99 \pm 0.28 \mathrm{a}$ \\
& Fereley & $40.93 \pm 0.35 \mathrm{~b}$ & $34.54 \pm 0.29 \mathrm{~b}$ & $33.70 \pm 0.22 \mathrm{~b}$ & $3.60 \pm 0.23 \mathrm{~b}$ \\
& Myrobalan & $40.85 \pm 0.32 \mathrm{~b}$ & $34.16 \pm 0.25 \mathrm{~b}$ & $33.09 \pm 0.21 \mathrm{~b}$ & $3.69 \pm 0.19 \mathrm{~b}$ \\
\hline
\end{tabular}

The same lowercase letters in the column indicate random differences between rootstocks for $R \leq 0.05$ by LSD test

The importance of fruit dimensions is that they are used to describe its shape, which is necessary for pomological research for various purposes, including the description of varieties and their inclusion in the records of certain registers (Beyer et al., 2002), the assessment of consumer preferences and the examination of the degree of inheritance fruit shape (White et al., 2000) or the degree of damage to the epidermis (Considine and Brown, 1981). Fruit shape plays an important role in both classification and calibration and also answers the question of how much fruit can be placed in shipping containers, standard packaging, or in plastic bags or bags of a given size (Keramat-Jahromi et al., 2008). Fruit dimensions are a major factor in determining the yield, quality of the fruit and acceptability by consumers (Crisosto et al., 2004).

According to data in Table 1, we noted that rootstocks affected the fruit firmness of the 'Čačanska Lepotica' and 'Čačanska Najbolja', while in the 'Čačanska Rana', there wasn't significant differences among the rootstocks. The highest values in 'Čačanska Lepotica' were obtained when grafted on Myrobalan and in 'Čačanska Najbolja' grafted on St. Julien A. The lowest values of fruit firmness were found in combination 'Čačanska Lepotica'/St. Julien A and 'Čačanska Najbolja'/Pixy. In addition to affecting quality, fruit firmness is a important indicator of its degree of maturity (Kawamura, 
2000). Kiprijanovsky and Ristevski (2009) reported that fruits should be harvested in the optimal state of ripeness, as this is the only way to produce fruits with adequate firmness. Rato et al. (2008) stated that the fruits of the 'Raínha Claudia Verde' grafted onto Mariana GF 8-1 and Mariana GF 10-2 rootstocks have significantly reduced the fruit firmness by ripening in storage. Variations influenced by the rootstocks were also observed.

It has been long known that fruit firmness is one of the most important physical characteristics that influenced the length of storage of the fruits and their timely release to the market. Producers are able to extend the time of marketing fruits by storing them in cold stores and thus slowing their ripening, that is, maintaining their firmness (Karaman et al., 2012). Numerous studies have shown that fruit firmness does not depend on the properties of the fruit skin, but on the time of harvest, degree of maturity and chemical composition of the fruit (Casquero and Guerra, 2009). Otherwise, fruit firmness values greater than $5.5 \mathrm{~kg} / \mathrm{cm}^{2}$ always result in unacceptable quality (Crisosto et al., 2005), so in this respect we can said that the fruits of our cultivars are of satisfactory quality.

Mohsenin (1986) pointed out the significance of other physical properties such as mean arithmetic and mean geometric diameter, sphericity and fruit surface. Namely, fruit arithmetic mean and geometric mean diameter are physical characteristics of great importance for estimating sample size, designing machines and determining certain processes in fruit and vegetable processing (Nunak and Suesut, 2007). These parameters depend on the type of fruit and variety, but also on environmental conditions, the intensity of planting measures, the position of the fruit in the canopy and maturity stage (Milošević et al., 2012). The knowledge related to geometric mean diameter would be valuable in designing the grading process (Mohsenin 1986, Çalışır et al., 2005).

Data relating to the arithmetic mean and geometric mean diameter are presented in Table 2. In general, rootstocks similarly influenced the arithmetic mean and geometric mean diameter of the fruits in all three varieties. Pixy is the rootstock that induced the lowest values for the previously mentioned parameters in all three cultivars.

'Čačanska Lepotica' and 'Čačanska Najbolja' showed the highest values when grafted on St. Julien A, while in 'Čačanska Rana' the highest values of the fruit arithmetic mean and geometric mean diameter were found when Myrobalan was used as rootstock. 
Table 2. Mean fruit arithmetic diameter, geometric mean diameter and sphericity of three plum varieties grafted on different rootstocks

\begin{tabular}{|c|c|c|c|c|}
\hline Cultivar & Rootstock & $\begin{array}{l}\text { Arithmetic mean } \\
\text { diameter } \\
(\mathrm{mm})\end{array}$ & $\begin{array}{l}\text { Geometric mean } \\
\text { diameter } \\
(\mathrm{mm})\end{array}$ & $\begin{array}{l}\text { Sphericity } \\
(\%)\end{array}$ \\
\hline \multirow[t]{4}{*}{ 'Čačanska Rana' } & Pixy & $41.20 \pm 0.21 \mathrm{c}$ & $40.92 \pm 0.20 \mathrm{c}$ & $0.85 \pm 0.00 \mathrm{a}$ \\
\hline & St. Julien A & - & - & - \\
\hline & Fereley & $43.34 \pm 0.18 b$ & $43.03 \pm 0.18 b$ & $0.85 \pm 0.00 \mathrm{a}$ \\
\hline & Myrobalan & $44.10 \pm 0.29 \mathrm{a}$ & $43.75 \pm 0.28 \mathrm{a}$ & $0.84 \pm 0.00 \mathrm{a}$ \\
\hline \multirow[t]{4}{*}{ 'Čačanska Lepotica' } & Pixy & $36.40 \pm 0.20 \mathrm{c}$ & $36.27 \pm 0.20 \mathrm{c}$ & $0.89 \pm 0.00 \mathrm{a}$ \\
\hline & St. Julien A & $37.67 \pm 0.21 \mathrm{a}$ & $37.56 \pm 0.21 \mathrm{a}$ & $0.90 \pm 0.00 \mathrm{a}$ \\
\hline & Fereley & $36.92 \pm 0.24 b$ & $36.81 \pm 0.24 \mathrm{~b}$ & $0.90 \pm 0.00 \mathrm{a}$ \\
\hline & Myrobalan & $36.53 \pm 0.37 \mathrm{bc}$ & $36.39 \pm 0.38 \mathrm{bc}$ & $0.90 \pm 0.01 \mathrm{a}$ \\
\hline \multirow[t]{4}{*}{ 'Čačanska Najbolja' } & Pixy & $34.73 \pm 0.24 \mathrm{c}$ & $34.56 \pm 0.24 \mathrm{c}$ & $0.87 \pm 0.00 \mathrm{~b}$ \\
\hline & St. Julien A & $38.03 \pm 0.27 \mathrm{a}$ & $37.87 \pm 0.26 \mathrm{a}$ & $0.88 \pm 0.00 \mathrm{ab}$ \\
\hline & Fereley & $36.39 \pm 0.25 \mathrm{ab}$ & $36.24 \pm 0.24 b$ & $0.89 \pm 0.00 \mathrm{a}$ \\
\hline & Myrobalan & $36.04 \pm 0.24 \mathrm{~b}$ & $35.86 \pm 0.23 \mathrm{~b}$ & $0.88 \pm 0.00 \mathrm{ab}$ \\
\hline
\end{tabular}

The same lowercase letters in the column indicate random differences between rootstocks for $R \leq 0.05$ by LSD test

The shape of the fruit is one of the most significant physical and qualitative parameter for all plant cultures (Kavdir and Guyer, 2004). Consumers prefer fruits of uniform size and uniform shape. Following global and local sorting and classification standards, deformed fruits are rejected (Waseem et al., 2002). Considering that, the classification of fruits based on shape and size can increase uniformity, reduce packaging costs and transport and can also provide optimum packaging configuration (Tabatabaeefar and Rajabipour, 2005).

Regarding sphericity, rootstocks significantly affected this trait only in 'Čačanska Najbolja', while in the other two varieties rootstock didn't caused significant differences. 'Cačanska Najbolja' had the highest sphericity value of the fruit on the Fereley and the lowest on the Pixy (Table 2).

Importance of testing sphericity of the fruit is reflected in the adjustment of the calibrator in the industrial processing of fruits, which increases the uniformity of the fruits, and thus reduces the cost of packaging and transport. This parameter is also useful in calculating the amount of energy required in processing (Milošević, 2013). Furthermore, Milošević et al. (2012) stated that there were no significant differences under the influence of rootstock in terms of sphericity in 'Jojo', 'Hanita' and 'Katinka' grafted on Wangenheim Prune. On the other hand, these authors emphasize the 
influence of rootstock on the relationship between the largest and smallest fruit dimensions. When the sphericity value is different from 1 (greater or less), the shape of the fruit is oval, flattened, or with convex sutures. All tested cultivars in our work had values of fruit sphericity below 1.0 indicating that the fruit is oval or elliptical. For example, Stefanova et al. (2008) reported that fruits of 'Hanita' have elliptical shape with well-marked abdominal suture. On the other hand, in study of Nenadović-Mratinić et al. (2007) plum cultivars had higher values than 1.0 which associated with an elongated shape.

\section{Conclusion}

The results obtained in this study showed that rootstock significantly influenced some physical-mechanical properties.

In 'Čačanska Najbolja', St. Julien A influenced the largest dimensions and in 'Cačanska Lepotica' the greatest length and thickness of the fruit. Myrobalan and Fereley had this effect in the 'Čačanska Rana'.

The highest value of fruit firmness of 'Čačanska Najbolja' was found when grafted on St. Julien A, and the smallest in 'Čačanska Lepotica' at the same rootstock.

'Čačanska Najbolja' and 'Čačanska Lepotica' had the highest values of arithmetic mean diameter and geometric mean diameter when grafted on St. Julien A.

In 'Čačanska Lepotica', sphericity is parameter that was not significantly affected by rootstock, while in 'Čačanska Najbolja', Ferley caused significantly higher values of sphericity than other rootstocks.

In our experiment, Pixy rootstock did not give satisfactory results. It depressingly affected all measured parameters of the fruit in combination with all varieties. Pixy made the reverse impact on three cultivars tested.

\section{Acknowledgement}

This study is part of the Project Ref. No. TR 31064 ("Creation and Preservation of the Genetic Potential of Temperate Fruits") financially supported by the Ministry of Education, Science and Technological Development of the Republic of Serbia. We acknowledge the financial and other types of assistance provided by the Ministry in implementing the project tasks.

\section{References}

Beyer M., Hahn R., Peschel S., Harz M., Knoche A. (2002): Analyzing fruit shape in sweet cherry (Prunus avium L.). Scientia Horticulturae, 96: 139-150.

Casquero P.A., Guerra M. (2009): Harvest parameters to optimise storage life of European plum 'Oullins Gage'. Food Science and Technology, 44: 2049-2054. 
Çalışır S., Hacıseferoĝulları H., Özcan M., Arslan D., (2005): Some nutritional and technological properties of wild plum (Prunus spp.) fruits in Turkey. Journal of Food Engineering, 66 (2): $233-237$.

Considine J., Brown K. (1981): Physical aspects of fruit growth-theoretical analysis of distribution of surface growth forces in fruit in relation to cracking and splitting. Plant Physiology, 68: 371-376.

Crisosto C.H., Crisosto G.M., Garner D. (2005): Understanding tree fruit consumer acceptance. Acta Horticulturae, 682: 865-870.

Crisosto C.H., Garner D., Crisosto G.M., Bowerman E. (2004): Increasing 'Blackamber' plum (Prunus salicina L.) consumer acceptance. Postharvest Biology and Technology, 34: 237-244.

FAOSTAT (2019): http://www.fao.org/faostat/en/\#data/QC

Karaman S., Ozturk B., Genc N., Celik S.M. (2012): Effect of preharvest aplication of methyl jasmonate on fruit quality of plum (Prunus salicina Lind. cv. 'Fortune') at harvest and during cold storage. Journal of Food Processing and Preservation, 10: 1745-1749.

Kavdir I., Guyer D.E. (2004): Comparasion of artifical neural networks and statistical classifiers in apple sorting using textural features. Biosystems Engineering, 89: 331-344.

Kawamura T. (2000): Relationship between skin color and maturity of japanase pear' Housui'. Japanese Journal of Farm Work Research, 35: 33-38.

Keramat-Jahromi M., Rafiee S., Jafari A., Ghasemi B.M.R., Mirasheh R., Mohtasebi S.S. (2008): Some physical properties of date fruit (cv. Dairi). International Agrophysics, 22: 221-224.

Kiprijanovski M., Ristevski B. (2009): Biological and pological characteristicks of some pear varieties in Republic of Macedonia. Agriculturae Conspectus Scientificus, 74: 123-126.

Milošević N. (2013): Stepen oplođenja i biološke osobine novih sorti šljive (Prunus domestica L.). Doktorska disertacija, Poljoprivreni fakultet, Beograd.

Milošević T., Milošević N. (2011): Quantitative analysis of the main biological and fruit quality traits of F1 plum genotypes (Prunus domestica L.). Acta Scientiarum Polonorum, Hortorum Cultus, 10 (2): 95-107.

Milošević N., Mratinić E., Glišić S.I., Milošević T. (2012): Precocity, yield and postharvest physical and chemical properties of plums resistant to Sharka grown in Serbian conditions. Acta Scientiarum Polonorum, Hortorum Cultus, 11: 23-33.

Milošević T., Milošević N. (2012): Factors influencing mineral composition of plum fruits. Journal of Elementology, 17 (3): 453-464.

Mišić P. (2002): Specijalno oplemenjivanje voćaka. Partenon i Institut „Srbija“, Beograd.

Mohsenin N.N. (1986): Physical properties of plant and animal materials. Gordon and Breach Press, New York, USA.

Nenadović-Mratinić E., Milatović D., Djurović D. (2007): Biološke osobine sorti šljive kombinovanih svojstava. Voćarstvo, 41: 31-35.

Nunak N., Suesut T. (2007): Measuring geometric mean diameter of fruit and vegetable using computer vision. In: PSU-UNS International Conference on Engineering and Environment ICEE-2007, Phuket, May 10-11, Songkhla, Thailand, pp. 144-148.

Paunović G., Milošević T., Glišić I. (2011): Morphometric traits of newly bred rootstock suckers in domestic and chery plum. Acta Scientiarum Polonorum, Hortorum Cultus, 10 (2): 203-212.

Paunović G. (2008): The selection of vegetative rootstocks for stone fruits. Acta Agriculturae Serbica, 26: 17-24. 
Rato E.A., Agulheiro C.A., Barroso M.J., Riquelme F. (2008): Soil and rootstock influence on fruit quality of plums (Prunus domestica L.). Scientia Horticulturae, 118 (3): 218-222.

Sosna I. (2002): Growth and cropping of four plum cultivars on different rootstocks in South Western Poland. Journal of Fruit and Ornamental Plant Research, 10: 95-103.

Stefanova B., Dinkova H., Dragoyski K., 2008. Plum cultivar Hanita in the Troyan conditions. Universitatea din Craiova, Seria: Biologie, Horticultură, Tehnologia prelucrării produselor agricole, Ingineria mediului, 13: 165-168.

Tabatabaeefar A., Rajabipour A. (2005): Modeling the mass of apples by geometrical attributes. Scientia Horticulturae, 105: 373-382.

Waseem K., Ghaffor A., Rehman S.U. (2002): Effect of fruit orientation on the quality of litchi (Litchi chinensis Sonn) under the agro-climatic conditions of Dera Ismail Khan-Pakistan. International Journal of Agriculture and Biology, 4: 503-505.

White A.G., Alspach P.A., Weskett R.H., Brewer L.R. (2000): Heritability of fruit shape in pear. Euphytica, 112: 1-7. 


\title{
UTICAJ PODLOGE NA FIZIČKO-MEHANIČKE OSOBINE PLODA ŠLJIVE (PRUNUS DOMESTICA L.)
}

\author{
Radmila Ilić, Ivan Glišić, Tomo Miloševié, Gorica Paunović
}

Katedra za voćarstvo i vinogradarstvo, Agronomski fakultet u Čačku, Univerzitet u Kragujevcu, Cara Dušana 34, 32000 Čačak, Srbija

\section{Rezime}

Istraživanje je obavljeno u eksperimentalno-proizvodnom zasadu šljive u toku 2013. godine. Ispititivane su najznačajnije fizičke osobine ploda tri sorte šljive ('Čačanska rana', 'Čačanska lepotica' i 'Čačanska najbolja') kalemljene na četiri podloge: jednoj generativnoj (Džanarika) i tri vegetativne (Pixy, St. Julien A i Ferley).

St. Julien A je kod Čačanske najbolje uticala na najveće dimenzije, a kod Čačanske lepotice na najveću dužinu i debljinu ploda. Ovakav uticaj kod Čačanske rane imale su podloge Džanarika i Fereley. Kod Čačanske najbolje podloga St. Julien A je uslovila najčvršći, a kod Čačanske lepotice najmekši mezokarp ploda.

Ključne reči: šljiva, sorta, dimenzije ploda, čvrstina mezokarpa. 